Article

\title{
Introducing Life Cycle Assessment in Costs and Benefits Analysis of Vegetation Management in Drainage Canals of Lowland Agricultural Landscapes
}

\author{
Elena Tamburini ${ }^{1}\left(\mathbb{D}\right.$, Elisa Soana ${ }^{1, *(\mathbb{D}}$, Mauro Monti ${ }^{2}$, Elisa Anna Fano ${ }^{1}(\mathbb{D}$ \\ and Giuseppe Castaldelli ${ }^{1}$ (D) \\ 1 Department of Life Sciences and Biotechnology, University of Ferrara, Via L. Borsari 46, 44121 Ferrara, Italy; \\ tme@unife.it (E.T.); fne@unife.it (E.A.F.); ctg@unife.it (G.C.) \\ 2 Consorzio di Bonifica Pianura di Ferrara, Via de' Romei 7, 44121 Ferrara, Italy; \\ mauro.monti@bonificaferrara.it \\ * Correspondence: elisa.soana@unife.it
}

Received: 29 June 2020; Accepted: 6 August 2020; Published: 8 August 2020

check for updates

\begin{abstract}
Nitrate pollution remains an unsolved issue worldwide, causing serious effects on water quality and eutrophication of freshwater and brackish water environments. Its economic costs are still underestimated. To reduce nitrogen excess, constructed wetlands are usually recognized as a solution but, in recent years, interest has been raised in the role of ditches and canals in nitrogen removal. In this study, we investigated the environmental and economical sustainability of nitrogen removal capacity, using as a model study a lowland agricultural sub-basin of the Po River (Northern Italy), where the role of aquatic vegetation and related microbial processes on the mitigation of nitrate pollution has been extensively studied. Based on the Life Cycle Assessment (LCA) approach and costs and benefits analysis (CBA), the effectiveness of two different scenarios of vegetation management, which differ for the timing of mowing, have been compared concerning the nitrogen removal via denitrification and other terms of environmental sustainability. The results highlighted that postponing the mowing to the end of the vegetative season would contribute to buffering up to $90 \%$ of the nitrogen load conveyed by the canal network during the irrigation period and would reduce by an order of magnitude the costs of eutrophication potential.
\end{abstract}

Keywords: LCA; CBA; nitrate pollution; canal network; vegetation management; mowing; denitrification

\section{Introduction}

A vast body of literature exists on the positive role of aquatic vegetation and in particular of emergent macrophytes, such as common reed (Phragmites australis) and cattail (Typha latifolia), in contrasting eutrophication and nitrogen $(\mathrm{N})$ pollution [1,2]. Surface flow wetlands are commonly used to mitigate $\mathrm{N}$ loads in urban and agricultural landscapes [3-5] and, more recently, studies have evidenced that this mitigation action may occur at a higher efficiency in canal networks, where emergent macrophytes spontaneously grow [6-8]. In ditches and canals, the most relevant mechanism involved in nitrate $\left(\mathrm{NO}_{3}{ }^{-}\right)$removal is denitrification, the reduction of $\mathrm{NO}_{3}{ }^{-}$to nitrogen gas $\left(\mathrm{N}_{2}\right)$, operated by bacteria under anaerobic conditions. It is considered as the most relevant biogeochemical process responsible globally for the permanent removal of anthropogenic reactive $\mathrm{N}$ along the terrestrial-freshwater-estuarine continuum $[9,10]$. In the specific case of the macrophytes-bacteria consortium, denitrification was demonstrated to occur quantitatively within the biofilms, which cover the submerged stems and leaves of emergent macrophytes [11,12].

Although canal networks are ubiquitous elements of agricultural watersheds, the acquisition of experimental evidence about their high $\mathrm{NO}_{3}{ }^{-}$mitigation potential, especially if vegetated, is so recent 
that is has not been adopted in protocols and plans to contrast eutrophication. Nowadays, aquatic vegetation is still considered only as a hindrance for water circulation, and is thus regularly removed by the water management authorities to preserve the hydraulic efficiency of the drainage networks [13-15]. This means that the idea that aquatic vegetation is a key component of the buffer capacity in agricultural landscapes and, at present, one of the few effective and low-cost tools, disregarded to date, to achieve the water quality goals of the Water Framework Directive has yet to be adopted [6,14,16].

The Po River basin, the largest Italian hydrographic system $\left(>71,000 \mathrm{~km}^{2}\right)$ flowing into the Northern Adriatic Sea, is a paradigmatic case study for the environmental policies related to eutrophication and widespread $\mathrm{NO}_{3}{ }^{-}$pollution, as one of the most agriculturally exploited and densely populated zones in Europe [17-19]. By its very nature as an enclosed sea, the Northern Adriatic Sea is especially impacted by widespread and persistent eutrophication processes [20]. The Burana-Volano-Navigabile (BVN), the deltaic portion of the Po river basin, represents an informative example of an intensively cropped territory crossed by an extensive network of mostly artificial canals and ditches, most of them with the double function of drainage and irrigation. The whole basin has been designated "vulnerable to nitrates from agricultural sources" following the enactment of the European Nitrates Directive (91/676/EEC) and the European Water Framework Directive (2000/60/EC) [21,22]. Most of the BVN basin drains into the Sacca di Goro, a shallow eutrophic lagoon affected, from the mid-1980s, by macroalgal blooms followed by anoxic crises and dystrophic outbreaks [23].

In the 1970s, after the advent of the hydraulic excavators, and in the late 1980s, with the introduction of new mechanical means for fast vegetation mowing, the canals of the BVN basin have progressively undergone the deepening of sections and, where possible, the removal of aquatic vegetation, aimed at decreasing the impediment to water flow. The development of new machines and techniques for mowing was necessary to contrast the invasive growth of submerged and emerging vegetation, which in the early 1980s had already grown out of control, preventing the water transit [24]. The excessive growth was mainly due to the increased use of synthetic fertilizers in agriculture, leading to high nutrient concentrations in runoff water reaching canals and ditches [18]. This series of cascading effects forced the local water management authorities to intensify mowing practices, which led to the almost complete removal of vegetation in most of the canal network [24]. Where it was not feasible to proceed mechanically, such as in the larger canals, the biological control of vegetation was used, by releasing a consistent amount of grass carp, Ctenopharingodon idella. This exotic species acclimated very well and quickly brought submerged vegetation to complete disappearance $[25,26]$. As a result, the residual vegetation is now composed only by emergent macrophytes (Phragmites australis, Typha latifolia, and Glyceria maxima), whose growth occurs only in some shallow reaches of the canal network with low hydraulic risk, representing, overall, $5 \%$ of the total canal length [6,27]. A detailed $\mathrm{N}$ input-output balance calculated in the BVN basin has shown that the canal network acts as a net $\mathrm{N}$ sink during the spring-summer months by partially buffering the $\mathrm{NO}_{3}{ }^{-}$load imported with irrigation water [21] Multiple experimental pieces of evidence collected in the same canals indicated that denitrification occurring in the vegetated portions of the canal network accounts for the majority of in-stream $\mathrm{N}$ removal $[27,28]$. Subsequent upscale studies in the same hydraulic-regulated and simplified watershed have shown that canal management may deeply affect the balance between $\mathrm{N}$ sources and sinks and, thus, also determine the quality of waters delivered to the coastal areas [6,29].

Nitrate pollution has serious environmental effects and may also cause threats to human health [30]. There is evidence of the causal effects of $\mathrm{NO}_{3}{ }^{-}$in drinking water on methemoglobinemia and increased incidence of colon cancer [31]. On the other hand, several efforts have been made to estimate the economic losses and potential societal costs due to human welfare and from human-induced environmental impacts, such as eutrophication [32]. Such costs, which are not part of any prices paid or direct compensation, are defined as externalities and might cause market distortions, encouraging activities that induce private benefits even if they are costly to the environment and society [33]. Currently, there is a lack of large consensus on accounting for the present and future values of ecosystem functions and potential economic costs deriving from their loss, even though the most 
recognized methodology to evaluate environmental and human health costs was to calculate the willingness to pay (WTP) to prevent damages and protect the environment from the perspective of society as a whole [34]. This was recently applied to the $\mathrm{N}$ social costs and benefits analysis by Brink and van Grinsven [35] and Keeler et al. [36].

To deepen the analysis of the conservative management of aquatic vegetation, we have investigated its economical and environmental sustainability by the means of a costs and benefits analysis based on Life Cycle Assessment (LCA). LCA is an accepted method that was used for years to evaluate the potential environmental impacts of a product or a service concerning its function and throughout its whole life cycle [37], including wastewater treatment plants and different nutrient removal technologies [38-40]. LCA can quantify the impacts, determining the aspects which influence the environmental performance most, and identifying possible improvement potentials. To the best of the authors' knowledge, this is the first attempt to link the results of environmental and economic analysis to evaluate different options of vegetation management in the canal network. In the present study, LCA has been used to compare the effectiveness of two scenarios on $\mathrm{N}$ abatement in the canal network of the BVN basin. The potential of the canal network to mitigate $\mathrm{NO}_{3}{ }^{-}$pollution was quantified for two levels of vegetation maintenance, i.e., $5 \%$, and $50 \%$ of the network total length. The $5 \%$ scenario corresponds to the present condition, while the more conservative $50 \%$ scenario is achieved only by postponing the mowing timing, from the middle of summer (present management) to the end of the vegetative season, in October. We hypothesize that this environmentally friendly choice, which may be sustainable also for the hydraulic security since it interests only half of the hydrological network length, may offer new management opportunities, reducing both the costs and environmental impacts and effectively contributing to mitigate $\mathrm{NO}_{3}{ }^{-}$loads.

\section{Materials and Methods}

\subsection{Study Area}

The BVN basin, accounting for $\sim 2600 \mathrm{~km}^{2}$ (Figure 1a), overlaps the administrative territory of the Ferrara Province (Emilia-Romagna Region, Northeastern Italy) and is bordered by the Adriatic Sea and the embankments of the Po, Reno and Panaro rivers. The basin is a completely flat territory, highly fertile and well served by irrigation, with all features favoring intensive farming, making agriculture the dominant land use ( $>85 \%$ of the basin area).

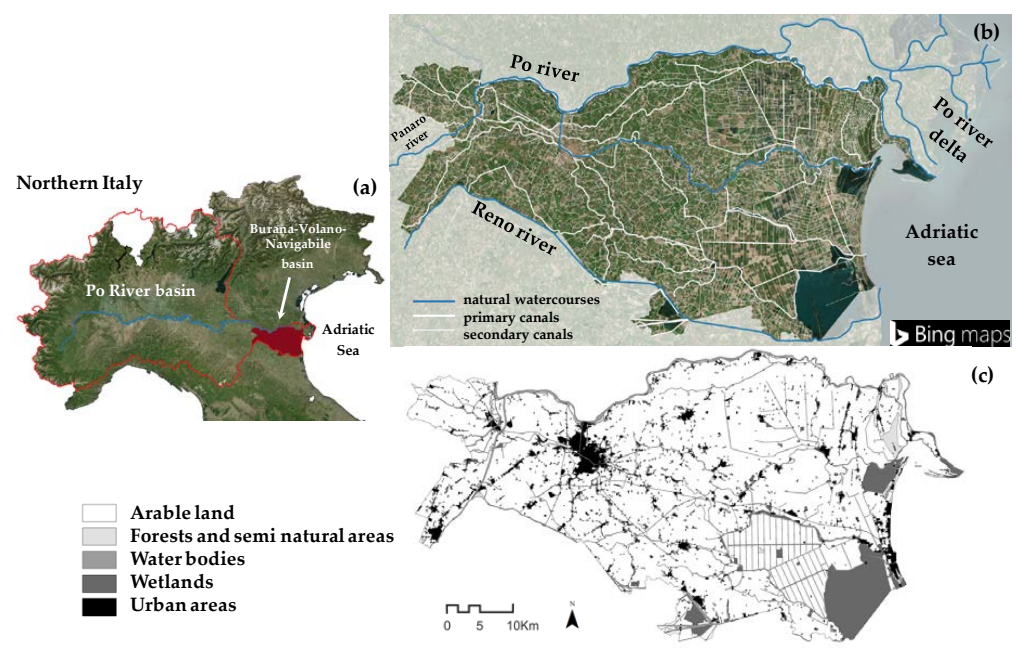

Figure 1. Study area: (a) location of the Burana-Volano-Navigabile basin in Northern Italy and within the Po River basin, (b) canal network map, and (c) land use/land cover map (source of vector data: Emilia-Romagna Region geoportal, http://geoportale.regione.emilia-romagna.it/it; on-line Bing aerial map background (C) 2020 Microsoft, Redmond, WA, USA; www.bing.com/maps), Baselayer for QGIS software, https://www.qgis.org/it/site/). 
The water used in the basin for irrigation is almost entirely derived from the Po river via mechanically controlled water diversion points and distributed to the arable lands through a capillary network of open-earth canals and ditches. The drainage of waters is artificially regulated by a complex system of main collectors converging towards several drainage plants that pump excess water out of the basin. The drainage system, managed by Ferrara Land Reclamation Consortium (Consorzio di Bonifica Pianura di Ferrara) and comprised of a network of $4208 \mathrm{~km}$ of canals (Figure 1b), 170 pumping stations and more than 13,000 hydraulic adjustment structures, is constantly operative to ensure hydraulic safety conditions for the Ferrara territory and water supply for agriculture during the irrigation period (from April to September).

\subsection{Vegetation Management in the Canal Network}

The Consorzio di Bonifica Pianura di Ferrara is one of the largest Land Reclamation Consortia in Italy for both contribution dimension and the extent of reclamation work (256,733 ha). It operates over a land district approximatively coinciding with the Ferrara provincial territory (263,500 ha), one of the most fertile zones of the Po Plain. Maintenance operations of the canal network (i.e., dredging, sediment removal, mechanical mowing, bank slope reinforcement, channel reshaping) are performed on a regular basis by the Consortium to maximize the conveyance capacity of the network, ensuring water drainage and water supply for irrigation. Similar to other irrigated watersheds [13,15], aquatic vegetation is routinely removed from the banks and the canal bottom using flail mowers, a standard procedure that has been in place in the BVN basin since the late 1980s and is carried out every year independently of a wet or dry summer season (Consorzio di Bonifica Pianura di Ferrara, personal communication). The mowing of in-stream emergent vegetation is performed once a year (in the middle of the summer, i.e., end of July, on 30\% of the total canal network length) in canals with low flood risk, or twice a year (in June and October, on 37\% of the total canal network length) in canals with high hydraulic risk. The remaining $33 \%$ is not subjected to mowing, since it accounts for canals with deep water column and high turbidity that prevent macrophyte development (Consorzio di Bonifica Pianura di Ferrara, personal communication).

\subsection{Calculation of the $N$ Removal Capacity of the Canal Network}

The potential capacity of the canal network to remove $\mathrm{N}$ via denitrification was predicted for the irrigation period (i.e., from April to September) under two scenarios: (1) current condition, where vegetation is present throughout the vegetative season in $5 \%$ of the total network length (95\% is considered completely unvegetated), and (2) conservative management, where vegetation is maintained throughout the vegetative season in $50 \%$ of the total network length by postponing the mowing operations to the end of the vegetative season. The end of the vegetative season corresponds to the end of the irrigation period when most of the canals switch from the primary function of irrigation to one of drainage. The mowing of in-stream vegetation is performed before the autumn period of intense rainfall, to maximize the discharge capacity of the drainage network.

The $\mathrm{N}$ removal capacity of the canal network under the two scenarios, i.e., actual and conservative, was estimated by employing a detailed upscale of extensive datasets of field measurements (i.e., water quality monitoring of the canal network, denitrification rates measured in vegetated and unvegetated canals) previously acquired in the study area $[6,12,27,28]$. Denitrification rates in the sediments of unvegetated canals $\left(\mathrm{Dr}_{\mathrm{UV}}\right)$ were calculated by applying the Christensen model [41], proposed for $\mathrm{NO}_{3}{ }^{-}$-rich agricultural waterways and previously tested in bare sediments of shallow slow-flow aquatic ecosystems of the Po River Plain, including several selected unvegetated canals of the BVN basin $[6,42,43]$. A good correlation was obtained between modeled and experimental rates along the $\mathrm{NO}_{3}{ }^{-}$concentration range 1-7 $\mathrm{mg} \mathrm{N} \mathrm{L}{ }^{-1}$, overlapping the $\mathrm{NO}_{3}{ }^{-}$availability detected in $\mathrm{NO}_{3}{ }^{-}$-rich agricultural streams employed for the validation of the model developed by Christensen 
and collaborators [41]. The denitrification rates of $\mathrm{NO}_{3}{ }^{-}$diffusing from the water column to the anoxic sediments were calculated according to the following equation:

$$
\operatorname{Dr}_{\mathrm{UV}}=\mathrm{SOD} \times 0.8 \times\left[\sqrt{1+0.82 \frac{\left[\mathrm{NO}_{3}^{-}\right]}{[-2]} \times \frac{1}{0.8}}-1\right],
$$

where:

- $\quad$ SOD is the sediment oxygen demand $\left(\mathrm{mg} \mathrm{O}_{2} \mathrm{~m}^{-2}\right.$ day $\left.^{-1}\right)$;

- $\left[\mathrm{NO}_{3}{ }^{-}\right]$and $\left[\mathrm{O}_{2}\right]$ are the concentrations of water column nitrate $\left(\mathrm{mg} \mathrm{N} \mathrm{L}^{-1}\right)$ and dissolved oxygen $\left(\mathrm{mg} \mathrm{O}_{2} \mathrm{~L}^{-1}\right)$, respectively;

- $\quad 0.8$ is the ratio between the activities per unit of volume in the sediment denitrification zone and in the oxygen respiration zone [44];

- 0.82 is the ratio between the diffusion coefficients of $\mathrm{NO}_{3}{ }^{-}$and $\mathrm{O}_{2}$ [41,44].

Low water velocities (a few centimeters per second) and a substrate characterized by a mixture of muddy sand or muddy silt are common features of the canals in the BVN basin. Reasonable estimates of SOD for canal sediments were calculated by applying an experimental equation, reported by Soana et al. (2019) [6]. The equation could predict the SOD as a function of water temperature and was obtained from a large dataset collected in several shallow slow-flow eutrophic environments of the Po River lowlands characterized by muddy sediments. Denitrification rates, obtained on an areal basis, were transformed into values expressed per unit of canal length $\left(\mathrm{kg} \mathrm{N} \mathrm{km}^{-1}\right.$ day $\left.^{-1}\right)$ by considering an average canal width of $3 \mathrm{~m}[27,28]$. Water quality datasets consisted of monthly values of water temperature, $\mathrm{NO}_{3}{ }^{-}$, and $\mathrm{O}_{2}$ concentrations collected in 15 stations over the period 2009-2018. The stations were located on the canal network of the Ferrara province and belonged to the official surface-water-monitoring network of the Emilia-Romagna Regional Agency for the Environmental Protection (ARPAE). The diffusion-reaction model by Christensen [41] was applied to all monthly ARPAE surveys for which measurements of water temperature, $\mathrm{NO}_{3}{ }^{-}$, and $\mathrm{O}_{2}$ concentrations were concomitantly available, thus a dataset of daily denitrification rates was obtained for each month, from April to September (Figure S1, Supplementary Materials).

Denitrification rates in vegetated canal sediments $\left(\mathrm{Dr}_{\mathrm{V}}\right)$, expressed per unit of canal length $\left(\mathrm{kg} \mathrm{N} \mathrm{km}^{-1} \mathrm{day}^{-1}\right)$, were calculated as a function of water $\mathrm{NO}_{3}{ }^{-}$availability $\left(\mathrm{mg} \mathrm{N} \mathrm{L}^{-1}\right)$ by employing a predictive relationship previous developed on a large dataset of experimental measurements of denitrification rates acquired in several vegetated canals of the studied area [6]:

$$
\mathrm{Dr}_{\mathrm{V}}=1.939 \times\left[\mathrm{NO}_{3}^{-}\right],
$$

The equation was applied to all monthly ARPAE surveys for which measurements $\mathrm{NO}_{3}{ }^{-}$ concentration were available, thus a dataset of daily denitrification rates was obtained for each month, from April to September (Figure S2, Supplementary Materials).

Daily denitrification rates calculated for unvegetated and vegetated sediments were extended, being assumed constant, to the number of days per month (from April to September) and the unvegetated and vegetated canal surfaces, respectively, under the two different management scenarios. To determine the likely variation in the $\mathrm{NO}_{3}{ }^{-}$removal capacity of the entire canal network, the interquartile range (first and third quartiles as inferior and superior extremes) of each monthly dataset of denitrification rates was considered. Monthly contributions, calculated for unvegetated and vegetated canals, were finally summed to obtain the total $\mathrm{N}$ amount removed in each month and at the annual scale by the whole canal network under the two different management scenarios. 


\subsection{LCA Methodology}

\subsubsection{Scope Definition, Functional Unit and System Boundaries}

The $\mathrm{N}$ removal capacity of the canal network, predicted under the two scenarios of vegetation management, was compared to the $\mathrm{N}$ load exported, during the vegetative season, by the canal network to the coastal lagoons and coastal waters, previously estimated by Castaldelli et al. [21]. This N load was obtained by combining measured discharge and $\mathrm{N}$ concentration dataset and represents the $\mathrm{N}$ output in the LCA scheme reported in Figure 2. The $\mathrm{N}$ input entering the canal network during the irrigation period was calculated by summing up the $\mathrm{N}$ load exported from the basin and the $\mathrm{N}$ removal capacity predicted under the current vegetation management. The scope of the LCA was to compare the environmental impacts of the current and the conservative vegetation managements on the $\mathrm{N}$ load conveyed by the same canal network and to provide potential environmental impacts for the quantification of costs and benefits. In the current management scenario, aquatic vegetation mowing is routinely carried as mentioned (Section 2.2), whereas in conservative management scenario, in 50\% of the canal network vegetation, mowing is performed only once a year, at the end of the vegetative season, in October, while the remaining $50 \%$ is managed following the current practice, with one or two mowing interventions, according to the hydraulic needs.

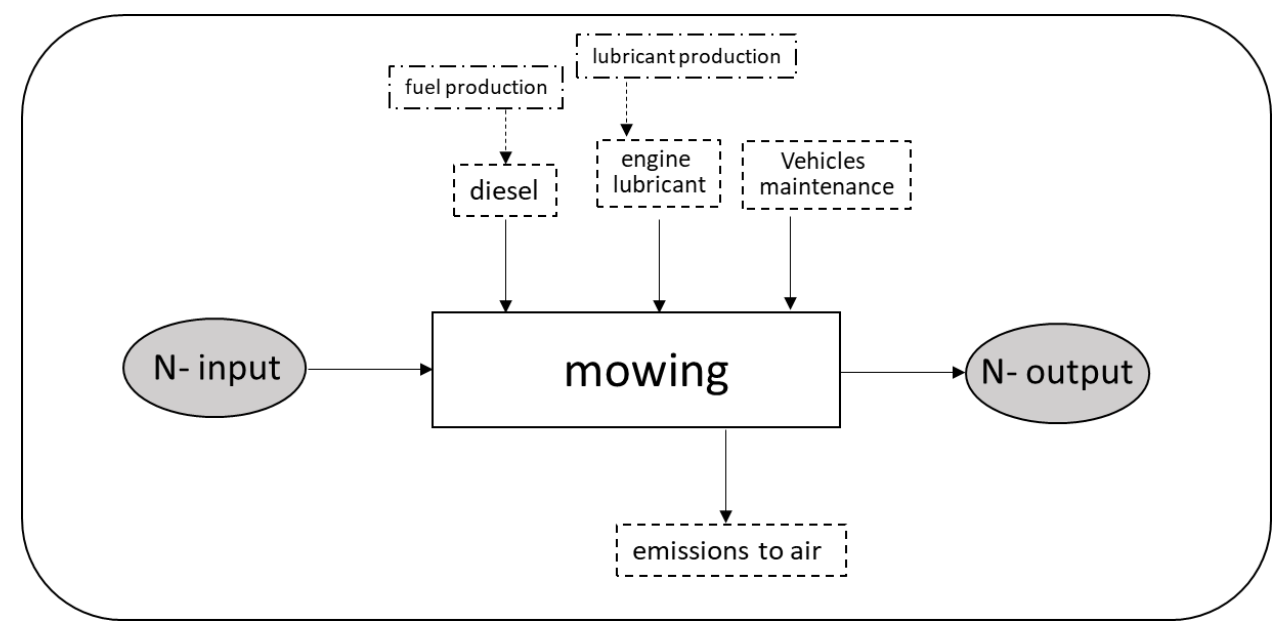

Figure 2. System boundaries used in the Life Cycle Assessment (LCA) of mowing operations in the canal network of the Burana-Volano-Navigabile (BVN) basin. The solid and dashed boxes represent foreground and background processes respectively. The dash-dot boxes represent the production of input materials; the solid arrows depict mass flows.

In LCA studies, the functional unit is a key element because it is the reference to which the inputs and outputs can be related and enables comparison of two or more different systems, whereas the system boundaries are selected to determine which unit processes have to be included in the LCA study. For both management options, the functional unit selected was $1 \mathrm{~km}$ of canal network (average depth, during the vegetative season, which is overlapped with the irrigation one, $0.5 \mathrm{~m}$; average width of the bottom $3 \mathrm{~m}$ ) and the system boundaries covered mechanical mowing operations on canals, diesel and lubricant oil production and consumption, vehicle maintenance and emissions in air related to fuel combustion (Figure 2). Vehicle production and transport from vehicle garages to canals are not included in the analysis, as well as fuel consumption for the other maintenance operations of canals (i.e., dredging, resectioning).

\subsubsection{Life Cycle Inventory (LCI) and Impact Calculations}

The inventory data are reported in Table 1 and were collected from a dedicated questionnaire submitted to the Ferrara Land Reclamation Consortium in 2020. Data collected for the present study 
covered the entire canals network of the hydrographic basin. For cleaning banks and canals, hydraulic mulching heads mounted on tractors and excavators with bucket-mowers are usually used, respectively. A type of trimmer equipped with a rotating cab and rotating mulching head was recently introduced for cutting vegetation in about $30 \%$ of the network length, reducing the number of forth and back passes necessary to complete the cutting, and consequently the amount of fuel consumed. After mowing operations, the residues (i.e., aboveground vegetation biomass) are usually left on the banks, so waste management has been neglected.

Table 1. Life cycle inventory (LCI) of canal network management in the current and conservative scenarios. All inputs are calculated for the functional unit of $1 \mathrm{~km}$ of canal.

\begin{tabular}{lcc}
\hline \multicolumn{1}{c}{ Parameter } & \multicolumn{2}{c}{ Input } \\
\cline { 2 - 3 } & Current Scenario & Conservative Scenario \\
\hline Materials and fuels & & \\
Diesel (l) & 61.9 & 53.05 \\
Engine oil (l) & 0.064 & 0.052 \\
\hline Emissions to air & & 138.21 \\
Carbon dioxide $(\mathrm{kg})$ & 161.35 & 1.85 \\
Nitrous oxide $(\mathrm{kg})$ & 2.16 & 0.044 \\
Sulfur oxide $(\mathrm{kg})$ & 0.052 & 0.11 \\
Non-methane volatile organic carbon $(\mathrm{NMVOC})(\mathrm{kg})$ & 0.14 & 0.19 \\
Particulates $(<10 \mu \mathrm{m})(\mathrm{kg})$ & 0.22 & 2011.2 \\
Heat, waste $(\mathrm{MJ})$ & 2347.9 & \\
\hline
\end{tabular}

All background data for fuel and engine oil productions, as well as for vehicle maintenance, were derived from Ecoinvent ${ }^{\mathrm{TM}}$ v3.6 (Ecoinvent Association, Zurich, Switzerland) [45] and Agribalyse $^{\mathrm{TM}}$ v1.3 (Ademe, Angers, France) [46] databases. The ReCiPe Midpoint (H) v1.11 (PRé Consultants, Amersfoort, The Netherlands) method [47] and the open source package OpenLCA ${ }^{\mathrm{TM}}$ v1.8 (GreenDelta, Berlin, Germany) were used for the impact assessment and the overall LCA modeling, respectively. Emissions to air were calculated directly by the software based on input data and mainly derived from diesel combustion. Impact categories are Eutrophication potential (EP), Global Warming Potential (GWP), Photochemical Oxidant Formation Potential (POFP), terrestrial Acidification potential (AP), Particulate Matter Formation potential (PMFP), Human Toxicity Potential (HTP) and Marine Aquatic Eco Toxicity Potential (MAETP). In this study, allocation was not necessary because the sole N flux was considered.

\subsubsection{Uncertainty Analysis}

The life cycle inventory (LCI) data were evaluated according to the semi-quantitative "pedigree matrix" [48], where all input data are scored (1 to 5, where 1 is better) based on the data quality features of reliability (sampling methods and verification procedures), completeness (statistical representativeness of the datum and periods for data collection), temporal, geographic and a further technological correlation (for data used outside its proper context). In Ecoinvent ${ }^{\mathrm{TM}}$, an uncertainty factor is assigned to each of the five data quality indicators [49] to calculate the total uncertainty of the result of each impact category, expressed as a 95\% confidence interval. The pedigree matrix and the uncertainty factors based on the data quality ratings were used for the Monte Carlo simulation (1000 runs).

\subsection{Costs and Benefits Analysis}

The results of the LCA were used to calculate the costs related to the different capacity of the ecosystem, i.e., the canal network under study, to remove $\mathrm{N}$ and thus mitigate the eutrophication potential, and to the potential release of pollutants in environment, related to the mechanical operations, 
in the two scenarios. To identify and analyze the annual costs for the environment, the damage costs concept was used [50] which takes into account possible outcomes to human health, linked to the release of pollutants. We assumed the definitions given by Mueller et al. [51] for ecological damage costs such as the loss of value of ecosystem services, and by Brink and van Grinsven [35] for human health costs, as the sum of market costs (i.e., medical treatments, productivity losses), non-market costs (i.e., individual's WTP to avoid the risk of pain and disease) and costs for life expectancy reduction caused by acute or prolonged inhalation of pollutants. The monetary values of environment and human health damages and the corresponding source used in this study are reported in Table 2.

Table 2. Unit damage costs for health and environmental impacts of nitrogen in water and other pollutants in air due to fuel combustion.

\begin{tabular}{|c|c|c|c|}
\hline Pollutant & Human Health or Environmental Impact & Unit Damage Cost $\left(€ \mathrm{~kg}^{-1}\right)$ & Reference \\
\hline $\mathrm{N}-\mathrm{NO}_{3}{ }^{-}$ & Eutrophication & 2.5 & [35] \\
\hline $\mathrm{N}-\mathrm{NO}_{3}{ }^{-}$ & Drinking water & 1.9 & [35] \\
\hline $\mathrm{CO}_{2}$ & Global warning & 0.03 & [50] \\
\hline PM10 & Respiratory, cardiovascular and lung disease & 24.87 & [52] \\
\hline $\mathrm{NO}_{x}$ & $\begin{array}{l}\text { Acidification and eutrophication of soil and water and } \\
\text { can lead to the formation of ground-level ozone }\end{array}$ & 10.72 & [52] \\
\hline $\mathrm{SO}_{2}$ & $\begin{array}{l}\text { Acidification, with potentially significant impacts } \\
\text { including adverse effects on aquatic ecosystems in } \\
\text { rivers and lakes, and damage to forests }\end{array}$ & 5.00 & [50] \\
\hline NMVOC & Directly hazardous on human health & 0.90 & [50] \\
\hline $1,4-\mathrm{DCB}$ * & $\begin{array}{l}\text { Deposition on terrestrial or water surfaces and can } \\
\text { bio-accumulate in food chains. }\end{array}$ & 209.4 & [53] \\
\hline
\end{tabular}

*1,4-dichlorobenzene, as the reference substance for human and environmental toxicity.

The potentiality of the canal network to remove $\mathrm{N}$, quantified for the two levels of vegetation maintenance (5\% and 50\%), was translated into an avoided cost. We used the replacement cost method for the economic valuation of the $\mathrm{N}$ removal function of the canal network by quantifying the cost that would be avoided in obtaining an equivalent $\mathrm{N}$ removal capacity by employing constructed wetlands [54,55]. Cost data for $\mathrm{N}$ removal in constructed wetlands (expressed in term of $€$ per $\mathrm{kg}$ of $\mathrm{N}$ removed) are scarce in Italy [56,57], so we adopted a literature range of costs (range $2-50 € \mathrm{~kg}^{-1} \mathrm{~N}$, average value $7 € \mathrm{~kg}^{-1} \mathrm{~N}$ ) of reducing $\mathrm{N}$ by means of surface flow constructed wetlands acquired in European agricultural landscapes with similar climate and anthropogenic pressures to the study area $[35,58,59]$.

\section{Results and Discussion}

The mowing of aquatic vegetation in the canal network determines the loss of multiple interfaces in water (biofilms) and benthic compartments (oxic-anoxic microniches in the rhizosphere) representing active denitrification hotspots responsible for the canal depuration capacity against $\mathrm{NO}_{3}{ }^{-}[3,8,11]$. The $\mathrm{N}$ removal performed by the canal network of the BVN basin under the current vegetation management was predicted in $385 \pm 55 \mathrm{t} \mathrm{N}$ year $^{-1}$, of which $>80 \%$ ascribed to unvegetated canal sediments (Figure 3). Summing up this $\mathrm{N}$ removal capacity to the $\mathrm{N}$ output to the coastal zone $\left(897 \pm 210 \mathrm{t} \mathrm{N}\right.$ year $\left.^{-1}\right)$ previously estimated by [21], the $\mathrm{N}$ input of $\sim 1280 \mathrm{t} \mathrm{N}$ year ${ }^{-1}$ was quantified, representing the $\mathrm{N}$ load generated the $\mathrm{BNV}$ basin during the spring-summer months. The predicted $\mathrm{N}$ abatement in the canal network would be by about three times, increasing up to $1145 \pm 177 \mathrm{t} \mathrm{N}^{\mathrm{Near}}{ }^{-1}$ in the case of postponing vegetation mowing to the end of the vegetative season in $50 \%$ of the network length (Figure 3). This increased capacity, almost completely due to the interfaces created by the presence of aquatic vegetation, would contribute to buffering $\sim 90 \%$ of the $\mathrm{N}$ load conveyed by the canal network during the irrigation period.

The results of LCAs of current and conservative scenarios are presented in Table 3. 


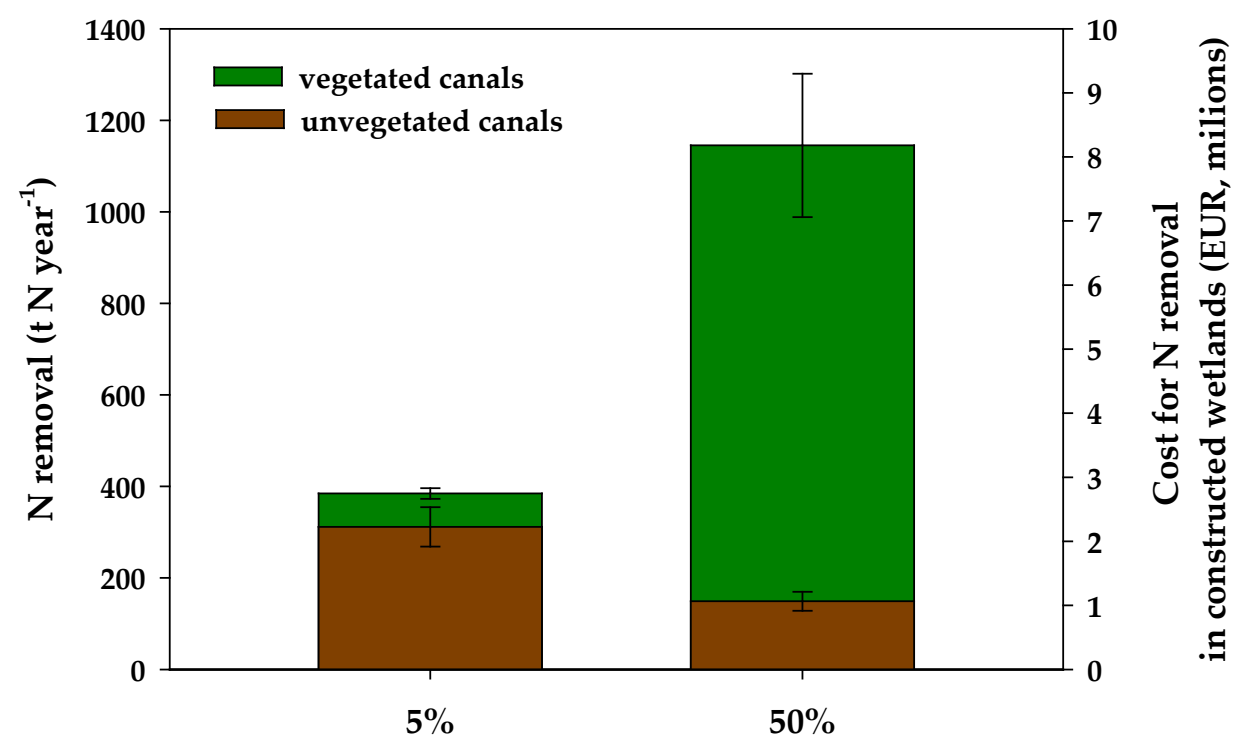

\section{Scenario of vegetation conservation \\ (\% of canal network length)}

Figure 3. Predicted $\mathrm{N}$ removal with vegetation conservation on 5\% (actual scenario) and 50\% (new scenario) of the canal network length. The corresponding cost for $\mathrm{N}$ removal in constructed wetlands is also reported.

Table 3. Impact categories results for current and conservative scenarios. All Impact categories are referred to 1 linear $\mathrm{km}$ of canal, during a whole vegetative season; $\mathrm{CV} \%$ was calculated from Montecarlo simulation (1000 runs).

\begin{tabular}{ccccc}
\hline Impact Category & Current Scenario & $\mathbf{C V} \%$ & Conservative Scenario & $\mathbf{C V} \%$ \\
\hline EP (kgN eq.) & 213.52 & $1 \%$ & 21.84 & $1 \%$ \\
GWP (kgCO 2 eq.) & 163.36 & $6 \%$ & 139.88 & $6 \%$ \\
POFP (kg NMVOC eq.) & 2.38 & $16 \%$ & 1.98 & $14 \%$ \\
AP (kg SO 2 eq.) & 1.30 & $21 \%$ & 1.08 & $20 \%$ \\
PMFP (kg PM10 eq.) & 0.76 & $24 \%$ & 0.60 & $25 \%$ \\
HTP (kg 1,4-DCB eq.) & 0.063 & $8 \%$ & 0.053 & $7 \%$ \\
MAETP (kg 1,4-DCB eq.) & 0.054 & $11 \%$ & 0.031 & $10 \%$ \\
\hline
\end{tabular}

Except for EP, which is affected by $\mathrm{N}$ loads, mostly as $\mathrm{NO}_{3}{ }^{-}$, carried by canals, all other impact categories are caused by the emissions of tractors. EP strongly depends on the $\mathrm{NO}_{3}{ }^{-}$loads transported by the canal network, and so the adoption of the conservative scenario, corresponds to a reduction of about $90 \%$ of the risk of eutrophication by the BVN basin in the terminal water bodies, i.e., the lagoons and coastal waters of the Po Delta. Thus, EP accounts for the environmental disturbance due to $\mathrm{NO}_{3}{ }^{-}$ pollution and the relative risk connected to phytoplankton and macroalgae blooms. These phenomena may lead to dissolved oxygen depletion and, ultimately, to long-lasting anoxia and dystrophy [23,60].

The other impact categories are mainly influenced by emissions to air caused by diesel combustion in tractors during vegetation mowing operations. In particular, nitrous oxides contribute to POFP, together with volatile organic compounds (NMVOC), both acting as precursors of the ground-level ozone layer, a harmful air pollutant being the main ingredient in smog, because of its effects on people and the environment [61]. Sulfur oxides contribute to AP, which measures the potential occurrence of atmospheric acidification, whereas human and environmental toxicity is due to traces of heavy metals (i.e., cadmium) in diesel-exhausted gases. GWP accounts for climate change deriving from the emissions of greenhouse gases in the air. GWP and EP values in the two scenarios are statistically different, unlike the other impact categories. In the study case, GWP is lower in the conservative 
scenario, because the new vegetation removal management in $50 \%$ of the canals network consists of a reduction in tractors' interventions and, consequently, lower fuel consumption. However, it has to be remarked that the effective benefit of the conservative strategy does not come from diminishing fuel consumption and emissions, but consists mainly in the EP reduction.

Multiplying unitary costs reported in Table 2 with the impact values as results of LCA in Table 3, the potential costs of damages on the environment and human health due to air emissions of fuel combustion by tractors, used for vegetation removal in the two scenarios were estimated (Table 4). As a result, in the current scenario, each kilometer of canal theoretically charges society and the environment almost 52 EUR per year, slightly more than the 44 EUR of the conservative ones.

Table 4. Potential costs of damages on human health and environment due to air emissions of fuel combustion for vegetation removal in $1 \mathrm{~km}$ of canal.

\begin{tabular}{ccc}
\hline Impact Category & Current Scenario (€) & Conservative Scenario (€) \\
\hline GWP (kgCO 2 eq.) & 4.7 & 4.0 \\
POFP (kg NMVOC eq.) & 2.0 & 1.8 \\
AP (kg SO 2 eq.) & 6.3 & 5.4 \\
PMFP (kg PM10 eq.) & 17.6 & 15.2 \\
HTP (kg 1,4-DCB eq.) & 13.2 & 11.3 \\
MAETP (kg 1,4-DCB eq.) & 7.70 & 6.6 \\
Total & 51.6 & 44.3 \\
\hline
\end{tabular}

For the entire canals network of the BVN basin, this means an overall potential extra-cost per year of about 206,000 EUR in the current scenario. These costs, which are comparable to those for the management of all structures of our societies, such as roads, rivers, and green areas, are still theoretical since they are not attributable to any public or private entity. Moreover, in our study case, the very low human density and the presence of a vegetation cover in the Spring-Summer season make the term almost irrelevant in the analysis of environmental sustainability, if compared to the same amount of emissions in an urban area. In the conservative scenario, potential costs due to air emissions of fuel combustion can be estimated at about 175,000 EUR per year, a value not markedly lower than in the previous case. On the other hand, between the two options of vegetation management (current and conservative) the main difference is not so much in terms of the number of mowing interventions or fuel consumption as it is in terms of the relevant benefits on the $\mathrm{N}$ balance in the canal network that could be achieved with the sole postponement of vegetation mowing to the end of the vegetative season.

The current denitrification capacity of the canal network was estimated at $385 \mathrm{t} \mathrm{N}$ year ${ }^{-1}$, which can save 243 EUR of potential costs calculated on the base of the eutrophication potential, per kilometer of canal (Table 5), corresponding to about 950.000 EUR, calculated on the overall BVN basin. However, in the conservative scenario, the $\mathrm{N}$ abatement in canals has been estimated at $1145 \mathrm{t} \mathrm{N}$ year $^{-1}$, more than three times higher than in the current scenario, corresponding to 722 EUR per $\mathrm{km}$ of canals, or circa 3 million EUR on the entire basin of avoided costs for the eutrophication potential. This saving of more than 2 million EUR, passing from the current to a more conservative scenario, may be achieved by simply postponing the mowing period.

It is worth noting that the more effective $\mathrm{NO}_{3}{ }^{-}$removal is purely the net-benefit of an ecosystem, provided by the interlinked action of aquatic emergent vegetation and microbial communities, which can be achieved without any further investment in equipment or machinery from public or private bodies. The only term which cannot be accounted for now, because it needs dedicated research, is the increase in hydraulic risk in the case of extreme meteoric events, whose occurrence is increasing in the study area due to global climate change. However, in the studied basin, with very low population density and in the season of interest, i.e., spring and summer, this risk is reasonably low and likely manageable with low costs.

In the literature, several experiences are reported regarding the strategies for mitigating $\mathrm{NO}_{3}{ }^{-}$ pollution in agricultural landscapes, mostly focused on limiting the losses from the fields, such as 
limitations in the quantity and timing of fertilizers' distribution [7,62], or at the interface between the mainland and transitional waters, such as the construction of artificial wetlands [63]. None of them is focused on the potential costs that could be avoided through exploiting the natural removal capacity of the canal network. The only data available on costs of $\mathrm{N}$ removal are related to the construction of artificial wetlands. Moreover, the cost of building and maintaining constructed wetlands to reduce $\mathrm{NO}_{3}{ }^{-}$emissions to superficial waters is largely site-specific, making any kind of comparison particularly difficult. Based on average data acquired in European agricultural landscape, it has been estimated

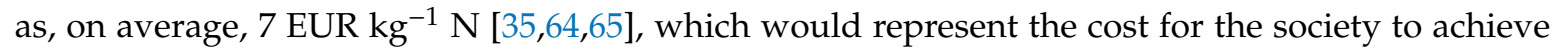
water depuration, to be added to the current cost for canal and ditch management in the basin. The denitrification capacity of the canal network predicted for the conservative vegetation scenario would equal an avoided cost of $\sim 8$ million EUR per year ( 2000 EUR per $\mathrm{km}$ of canal per year) obtaining an equivalent $\mathrm{N}$ abatement by employing constructed wetlands (Figure 2). The decrease in EP in the conservative management scenario would bring a substantial reduction in $\mathrm{NO}_{3}{ }^{-}$loads, very likely leading to the achievement of an ecological good state in the coastal waters, fulfilling the requirements of the WFD. In monetary terms, this decrease in EP would equal a net saving of about $\sim 5$ million with respect to the current scenario (Figure 2), otherwise needed for the $\mathrm{N}$ abatement by employing artificial wetlands.

Table 5. Potential costs avoided based on nitrogen metabolic capacity of canals and ditches and potential damage costs for the remaining $\mathrm{N}$ output in current and conservative scenarios, calculated per kilometer of canals.

\begin{tabular}{ccc}
\hline Scenario & $\begin{array}{c}\text { Potential Costs Avoided } \\
\text { (EUR) }\end{array}$ & $\begin{array}{c}\text { Potential Remaining Costs for } \\
\text { Environmental Damage (EUR) }\end{array}$ \\
\hline Current & 243.0 & 533.8 \\
Conservative & 722.0 & 54.6 \\
\hline
\end{tabular}

\section{Conclusions}

The results of this study highlighted that the implementation of conservative management practices of in-stream vegetation significantly improves the N removal capacity of the canal network, resulting in an increased net benefit for the society. This can be seen as one of the positive externalities, i.e., multiple environmental benefits for the society, that water-managing authorities provide through their operations in the canal network. It equals also to a net increase in sustainability in the management of an agricultural basin, which is quantitatively more important for the reduction in the eutrophication potential but also for the decrease in atmospheric emissions. We have to point out that the economic analysis still needs to be implemented with the evaluation of the works needed to maintain hydraulic security in the conservative scenario. However, the economic quantification done in this paper is the first step for including this paramount ecosystem function (i.e., $\mathrm{N}$ removal) in the overall management budget of these environments, in addition to the conventional hydraulic functions.

Supplementary Materials: The following are available online at http://www.mdpi.com/2073-4441/12/8/2236/s1, Figure S1: Daily rates of denitrification calculated for unvegetated canal sediments of the Burana-Volano-Navigabile watershed by applying the model proposed by Christensen et al. (1990) [41]. Box and Whisker plots include the predicted rates for 15 stations located on the canal network of the Ferrara province and belonging to the official surface water monitoring network of the Emilia-Romagna Regional Agency for the Environmental Protection. Central horizontal line in the box is the median, top and bottom boxes are 25th and 75th percentiles, and whiskers are 10th and 90th percentiles. Outliers are showed as open circles. Figure S2: Daily rates of denitrification calculated for vegetated canal sediments of the Burana-Volano-Navigabile watershed by applying the experimental relationship reported by Soana et al. (2019) [6]. Box and Whisker plots include the predicted rates for 15 stations located on the canal network of the Ferrara province and belonging to the official surface water monitoring network of the Emilia-Romagna Regional Agency for the Environmental Protection. Central horizontal line in the box is the median, top and bottom boxes are 25th and 75th percentiles, and whiskers are 10th and 90th percentiles. Outliers are showed as open circles. 
Author Contributions: Conceptualization, G.C.; methodology and formal analysis, E.T. and E.S.; resources, M.M.; writing-original draft preparation, G.C., E.T. and E.S.; writing-review and editing, E.S.; visualization, E.S.; supervision, E.A.F. All authors have read and agreed to the published version of the manuscript.

Funding: This research was partly funded by the Emilia-Romagna Region within the Rural Development Program (PSR) 2014-2020 (Measure 16.1.01-Operational Groups of the European Partnership for Agricultural Productivity and Sustainability Focus Area 4B-Improved management of water resources, included the limitation of fertilizers and pesticides, Grant $n^{\circ} 5005490$ ), Project Ferrara Nitrates-Agricultural techniques to prevent nitrates pollution and for the organic matter conservation (https://ec.europa.eu/eip/agriculture/en/find-connect/projects/nitratiferrara-tecniche-agronomiche-la).

Acknowledgments: The authors want to thank the President of the Consorzio di Bonifica Pianura di Ferrara, Franco Dalle Vacche, for the foresight in welcoming this research, for having authorized the supply of the data necessary and for the development of increasingly sustainable water management. We acknowledge the Emilia-Romagna Regional Agency for the Environmental Protection for providing water quality data.

Conflicts of Interest: The authors declare no conflict of interest.

\section{References}

1. Vymazal, J. Plants used in constructed wetlands with horizontal subsurface flow: A review. Hydrobiologia 2011, 674, 133-156. [CrossRef]

2. Rezania, S.; Park, J.; Rupani, P.F.; Darajeh, N.; Xu, X.; Shahrokhishahraki, R. Phytoremediation potential and control of Phragmites australis as a green phytomass: An overview. Environ. Sci. Pollut. Res. 2019, 26, 7428-7441. [CrossRef] [PubMed]

3. Messer, T.L.; Burchell, M.R., II; Birgand, F.; Broome, S.W.; Chescheir, G. Nitrate removal potential of restored wetlands loaded with agricultural drainage water: A mesocosm scale experimental approach. Ecol. Eng. 2017, 106, 541-554. [CrossRef]

4. Laterra, P.; Booman, G.C.; Picone, L.; Videla, C.; Orúe, M.E. Indicators of nutrient removal efficiency for riverine wetlands in agricultural landscapes of Argentine Pampas. J. Environ. Manag. 2018, 222, 148-154. [CrossRef] [PubMed]

5. Uusheimo, S.; Huotari, J.; Tulonen, T.; Aalto, S.L.; Rissanen, A.J.; Arvola, L. High nitrogen removal in a constructed wetland receiving treated wastewater in a cold climate. Environ. Sci. Technol. 2018, 52, 13343-13350. [CrossRef]

6. Soana, E.; Bartoli, M.; Milardi, M.; Fano, E.A.; Castaldelli, G. An ounce of prevention is worth a pound of cure: Managing macrophytes for nitrate mitigation in irrigated agricultural watersheds. Sci. Total. Environ. 2019, 647, 301-312. [CrossRef]

7. Goeller, B.C.; Febria, C.M.; McKergow, L.A.; Harding, J.S.; Matheson, F.E.; Tanner, C.C.; McIntosh, A.R. Combining tools from edge-of-field to in-stream to attenuate reactive nitrogen along small agricultural waterways. Water 2020, 12, 383. [CrossRef]

8. Taylor, J.; Moore, M.; Speir, S.L.; Testa, S. Vegetated Ditch Habitats Provide Net Nitrogen Sink and Phosphorus Storage Capacity in Agricultural Drainage Networks Despite Senescent Plant Leaching. Water 2020, 12, 875. [CrossRef]

9. Seitzinger, S.; Harrison, J.A.; Böhlke, J.K.; Bouwman, A.F.; Lowrance, R.; Peterson, B.; Tobias, C.; Drecht, G.V. Denitrification across landscapes and waterscapes: A synthesis. Ecol. Appl. 2006, 16, 2064-2090. [CrossRef]

10. Kulkarni, M.V.; Groffman, P.M.; Yavitt, J.B. Solving the global nitrogen problem: It's a gas! Front. Ecol. Environ. 2008, 6, 199-206. [CrossRef]

11. Soana, E.; Gavioli, A.; Tamburini, E.; Fano, E.A.; Castaldelli, G. To mow or not to mow: Reed biofilms as denitrification hotspots in drainage canals. Ecol. Eng. 2018, 113, 1-10. [CrossRef]

12. Soana, E.; Gavioli, A.; Vincenzi, F.; Fano, E.A.; Castaldelli, G. Nitrate availability affects denitrification in Phragmites australis sediments. J. Environ. Qual. 2020, 49, 194-209. [CrossRef]

13. Levavasseur, F.; Biarnès, A.; Bailly, J.S.; Lagacherie, P. Time-varying impacts of different management regimes on vegetation cover in agricultural ditches. Agric. Water Manag. 2014, 140, 14-19. [CrossRef]

14. Dollinger, J.; Dagès, C.; Bailly, J.S.; Lagacherie, P.; Voltz, M. Managing ditches for agroecological engineering of landscape. A review. Agron. Sustain. Dev. 2015, 35, 999-1020. [CrossRef] 
15. Errico, A.; Lama, G.F.C.; Francalanci, S.; Chirico, G.B.; Solari, L.; Preti, F. Flow dynamics and turbulence patterns in a drainage channel colonized by common reed (Phragmites australis) under different scenarios of vegetation management. Ecol. Eng. 2019, 133, 39-52. [CrossRef]

16. Rowiński, P.M.; Västilä, K.; Aberle, J.; Järvelä, J.; Kalinowska, M.B. How vegetation can aid in coping with river management challenges: A brief review. Ecohydrol. Hydrobiol. 2018, 18, 345-354. [CrossRef]

17. Martinelli, G.; Dadomo, A.; De Luca, D.A.; Mazzola, M.; Lasagna, M.; Pennisi, M.; Pilla, G.; Sacchi, E.; Saccon, P. Nitrate sources, accumulation and reduction in groundwater from Northern Italy: Insights provided by a nitrate and boron isotopic database. Appl. Geochem. 2018, 91, 23-35. [CrossRef]

18. Viaroli, P.; Soana, E.; Pecora, S.; Laini, A.; Naldi, M.; Fano, E.A.; Nizzoli, D. Space and time variations of watershed $\mathrm{N}$ and $\mathrm{P}$ budgets and their relationships with reactive $\mathrm{N}$ and $\mathrm{P}$ loadings in a heavily impacted river basin (Po river, Northern Italy). Sci. Total Environ. 2018, 639, 1574-1587. [CrossRef]

19. Malagó, A.; Bouraoui, F.; Pastori, M.; Gelati, E. Modelling Nitrate reduction strategies from diffuse sources in the Po River Basin. Water 2019, 11, 1030. [CrossRef]

20. Viaroli, P.; Nizzoli, D.; Pinardi, M.; Soana, E.; Bartoli, M. Eutrophication of the Mediterranean Sea: A watershed-Cascading aquatic filter approach. Rend. Fis. Acc. Lincei 2015, 26, 13-23. [CrossRef]

21. Castaldelli, G.; Soana, E.; Racchetti, E.; Pierobon, E.; Mastrocicco, M.; Tesini, E.; Fano, E.A.; Bartoli, M. Nitrogen budget in a lowland coastal area within the Po river basin (Northern Italy): Multiple evidences of equilibrium between sources and internal sinks. Environ. Manag. 2013, 52, 567-580. [CrossRef] [PubMed]

22. Emilia-Romagna Region. Water Protection Plan. 2006. Available online: https://ambiente.regione.emiliaromagna.it/it/acque/approfondimenti/documenti/piano-di-tutela-delle-acque/water-protection-planstrategic-contents-of-policies/piano_tutela_acque_english.pdf (accessed on 9 June 2020).

23. Viaroli, P.; Giordani, G.; Bartoli, M.; Naldi, M.; Azzoni, R.; Nizzoli, D.; Ferrari, I.; Zaldívar Comenges, J.M.; Bencivelli, S.; Castaldelli, G.; et al. The Sacca di Goro lagoon and an arm of the Po River. In Estuaries. The Handbook of Environmental Chemistry; Wangersky, P.J., Ed.; Springer: Berlin/Heidelberg, Germany, 2006; Volume 5H, pp. 197-232.

24. Melotti, P.; Resta, C.; Cavallari, A. La Carpa Erbivora in Emilia-Romagna Aspetti Biologici e Gestionali; Regione Emilia-Romagna e Amministrazione Provinciale di Ferrara: Ferrara, Italy, 1987. (In Italian)

25. Milardi, M.; Lanzoni, M.; Kiljunen, M.; Torniainen, J.; Castaldelli, G. Natural recruitment contributes to high densities of grass carp Ctenopharyngodon idella (Valenciennes, 1844) in Western Europe. Aquat. Invasions 2015, 10, 439-448. [CrossRef]

26. Milardi, M.; Soana, E.; Chapman, D.; Fano, E.A.; Castaldelli, G. Could a freshwater fish be at the root of dystrophic crises in a coastal lagoon? Sci. Total Environ. 2020, 711, 135093. [CrossRef] [PubMed]

27. Pierobon, E.; Castaldelli, G.; Mantovani, S.; Vincenzi, F.; Fano, E.A. Nitrogen removal in vegetated and unvegetated drainage ditches impacted by diffuse and point sources of pollution. CLEAN Soil Air Water 2013, 41, 24-31. [CrossRef]

28. Castaldelli, G.; Soana, E.; Racchetti, E.; Vincenzi, F.; Fano, E.A.; Bartoli, M. Vegetated canals mitigate nitrogen surplus in agricultural watersheds. Agric. Ecosyst. Environ. 2015, 212, 253-262. [CrossRef]

29. Castaldelli, G.; Vincenzi, F.; Fano, E.A.; Soana, E. In search for the missing nitrogen: Closing the budget to assess the role of denitrification in agricultural watersheds. Appl. Sci. 2020, 10, 2136. [CrossRef]

30. Dodds, W.K.; Bouska, W.W.; Eitzmann, J.L.; Pilger, T.J.; Pitts, K.L.; Riley, A.J.; Thornbrugh, D.J. Eutrophication of US freshwaters: Analysis of potential economic damages. Environ. Sci. Technol. 2009, 43, 12-19. [CrossRef]

31. De Roos, A.J.; Ward, M.H.; Lynch, C.F.; Cantor, K.P. Nitrate in public water supplies and the risk of colon and rectum cancers. Epidemiology 2003, 14, 640-649. [CrossRef]

32. Schoen, M.E.; Xue, X.; Wood, A.; Hawkins, T.R.; Garland, J.; Ashbolt, N.J. Cost, energy, global warming, eutrophication and local human health impacts of community water and sanitation service options. Water Res. 2017, 109, 186-195.

33. Pretty, J.N.; Mason, C.F.; Nedwell, D.B.; Hine, R.E.; Leaf, S.; Dils, R. Environmental costs of freshwater eutrophication in England and Wales. Environ. Sci. Technol. 2003, 37, 201-208. [CrossRef]

34. Combes, J.L.; Hamit-Haggar, M.; Schwartz, S. A multilevel analysis of the determinants of willingness to pay to prevent environmental pollution across countries. J. Soc. Sci. 2018, 55, 284-299. [CrossRef] 
35. Brink, C.; Van Grinsven, H. Costs and benefits of nitrogen in the environment. In The European Nitrogen Assessment: Sources, Effects and Policy Perspectives; Sutton, M., Howard, C., Erisman, J., Billen, G., Bleeker, A., Grennfelt, P., van Grinsven, H., Grizzetti, B., Eds.; Cambridge University Press: Cambridge, UK, 2011; pp. 513-540.

36. Keeler, B.L.; Gourevitch, J.D.; Polasky, S.; Isbell, F.; Tessum, C.W.; Hill, J.D.; Marshall, J.D. The social costs of nitrogen. Sci. Adv. 2016, 2, e1600219. [CrossRef] [PubMed]

37. ISO. Environmental Management_Life Cycle Assessment, Principles and Framework: International Standard 14040; International Standards Organisation: Geneva, Switzerland, 2006.

38. Corominas, L.; Larsen, H.F.; Flores-Alsina, X.; Vanrolleghem, P.A. Including life cycle assessment for decision-making in controlling wastewater nutrient removal systems. J. Environ. Manag. 2013, 128, 759-767. [CrossRef] [PubMed]

39. Coats, E.R.; Watkins, D.L.; Kranenburg, D. A Comparative Environmental Life-Cycle Analysis for Removing Phosphorus from Wastewater: Biological versus Physical/Chemical Processes. Water. Environ. Res. 2011, 83, 750-760. [CrossRef] [PubMed]

40. Godin, D.; Bouchard, C.; Vanrolleghem, P.A. Net environmental benefit: Introducing a new LCA approach on wastewater treatment systems. Water Sci. Technol. 2012, 65, 1624-1631. [CrossRef] [PubMed]

41. Christensen, P.B.; Nielsen, L.P.; Sørensen, J.; Revsbech, N.P. Denitrification in nitrate-rich streams: Diurnal and seasonal variation related to benthic oxygen metabolism. Limnol. Oceanogr. 1990, 35, 640-651. [CrossRef]

42. Pinardi, M.; Bartoli, M.; Longhi, D.; Marzocchi, U.; Laini, A.; Ribaudo, C.; Viaroli, P. Benthic metabolism and denitrification in a river reach: A comparison between vegetated and bare sediments. J. Limnol. 2009, 68, 133-145. [CrossRef]

43. Racchetti, E.; Bartoli, M.; Soana, E.; Longhi, D.; Christian, R.R.; Pinardi, M.; Viaroli, P. Influence of hydrological connectivity of riverine wetlands on nitrogen removal via denitrification. Biogeochemistry 2011, 103, 335-354. [CrossRef]

44. Nielsen, L.P.; Christensen, P.B.; Revsbech, N.P.; Sørensen, J. Denitrification and oxygen respiration in biofilms studied with a microsensor for nitrous oxide and oxygen. Microb. Ecol. 1990, 19, 63-72. [CrossRef]

45. Ecoinvent Database ${ }^{\circledR}$. Available online: https://www.ecoinvent.org/database/database.html (accessed on 20 April 2020).

46. AGRIBALYSE Agricultural Database ${ }^{\circledR}$. Available online: https://simapro.com/products/agribalyseagricultural-database (accessed on 19 April 2020).

47. ReCiPe ${ }^{\circledR}$. Available online: https://www.pre-sustainability.com/recipe (accessed on 19 April 2020).

48. Yu, B.; Liu, Q.; Gu, X. Data quality and uncertainty assessment methodology for pavement LCA. Int. J. Pavement Eng. 2018, 19, 519-525. [CrossRef]

49. Ciroth, A.; Muller, S.; Weidema, B.; Lesage, P. Empirically based uncertainty factors for the pedigree matrix in ecoinvent. Int. J. Life Cycle Assess. 2016, 21, 1338-1348. [CrossRef]

50. Friedrich, R.; Rabl, A.; Spadaro, J.V. Quantifying the costs of air pollution: The ExternE project of the EC. Pollut. Atmos. 2001, 77-104.

51. Mueller, H.; Hamilton, D.P.; Doole, G.J. Evaluating services and damage costs of degradation of a major lake ecosystem. Ecosyst. Serv. 2016, 22, 370-380. [CrossRef]

52. Brand, C.; Hunt, A. The Health Costs of Air Pollution from Cars and Vans. Clean Air Day. Available online: https://www.cleanairday.org.uk/news/the-health-costs-ofair-pollution-from-cars-and-vans (accessed on 28 March 2018).

53. Nedellec, V.; Rabl, A. Costs of health damage from atmospheric emissions of toxic metals: Part 1-Methods and results. Risk Anal. 2016, 36, 2081-2095. [CrossRef] [PubMed]

54. Boerema, A.; Schoelynck, J.; Bal, K.; Vrebos, D.; Jacobs, S.; Staes, J.; Meire, P. Economic valuation of ecosystem services, a case study for aquatic vegetation removal in the Nete catchment (Belgium). Ecosyst. Serv. 2014, 7, 46-56. [CrossRef]

55. Grossmann, M. Economic value of the nutrient retention function of restored floodplain wetlands in the Elbe River basin. Ecol. Econ. 2011, 83, 108-117. [CrossRef]

56. Romagnoli, F. La Fitodepurazione: Manuale Tecnico Divulgativo per una Gestione Sostenibile del Ciclo Delle Acque; CEAS-Centro di Educazione all'Ambiente e alla Sostenibilità: Comune di Reggio Emilia, Italy, 2002; p. 112. Available online: https://www.comune.re.it/retecivica/urp/retecivi.nsf/PESDocumentID/ 4B81259D754869F4C1257826004522FD?opendocument\&FROM=Pbblczn2 (accessed on 9 June 2020). 
57. ISPRA (Italian Institute for Environmental Protection and Research). Guida tecnica per la progettazione e gestione dei sistemi di fitodepurazione per il trattamento delle acque reflue urbane. In Manuali e Linee Guida 81/2012; ISPRA: Roma, Italy, 2012; p. 164. Available online: https://www.isprambiente.gov.it/files/ pubblicazioni/manuali-lineeguida/Manuale_81_2012.pdf (accessed on 9 June 2020).

58. Gachango, F.G.; Pedersen, S.M.; Kjærgaard, C. Cost-effectiveness analysis of surface flow constructed wetlands (SFCW) for nutrient reduction in drainage discharge from agricultural fields in Denmark. Environ. Manag. 2015, 56, 1478-1486. [CrossRef]

59. Jensen, A.K.; Uggeldahl, K.C.; Jacobsen, B.H.; Jensen, J.D.; Hasler, B. Including aesthetic and recreational values in cost-effectiveness analyses of land use change based nitrogen abatement measures in Denmark. J. Environ. Manag. 2019, 240, 384-393. [CrossRef]

60. Anderson, D.M.; Glibert, P.M.; Burkholder, J.M. Harmful algal blooms and eutrophication: Nutrient sources, composition, and consequences. Estuaries 2002, 25, 704-726. [CrossRef]

61. Goudarzi, G.; Geravandi, S.; Foruozandeh, H.; Babaei, A.A.; Alavi, N.; Niri, M.V.; Mohammadi, M.J. Cardiovascular and respiratory mortality attributed to ground-level ozone in Ahvaz, Iran. Environ. Monit. Assess. 2015, 187, 487. [CrossRef]

62. Teshager, A.D.; Gassman, P.W.; Secchi, S.; Schoof, J.T. Simulation of targeted pollutant-mitigation-strategies to reduce nitrate and sediment hotspots in agricultural watershed. Sci. Total Environ. 2017, 607, 1188-1200. [CrossRef] [PubMed]

63. van Biervliet, O.; McInnes, R.J.; Lewis-Phillips, J.; Tosney, J. Can an integrated constructed wetland in Norfolk reduce nutrient concentrations and promote in situ bird species richness? Wetlands 2020. [CrossRef]

64. Christianson, L.; Knoot, T.; Larsen, D.; Tyndall, J.; Helmers, M. Adoption potential of nitrate mitigation practices: An ecosystem services approach. Int. J. Agric. Sustain. 2014, 12, 407-424. [CrossRef]

65. Carstensen, M.V.; Hashemi, F.; Hoffmann, C.C.; Zak, D.; Audet, J.; Kronvang, B. Efficiency of mitigation measures targeting nutrient losses from agricultural drainage systems: A review. Ambio 2020. [CrossRef] [PubMed]

(C) 2020 by the authors. Licensee MDPI, Basel, Switzerland. This article is an open access article distributed under the terms and conditions of the Creative Commons Attribution (CC BY) license (http://creativecommons.org/licenses/by/4.0/). 